\title{
Patterns of recovery in catastrophically disturbed reef fish assemblages
}

\author{
Andrew R. Halford ${ }^{1,3, *}$, Johan Perret $^{2}$ \\ ${ }^{1}$ Australian Institute of Marine Science, PMB \#3, TMC, Townsville, Queensland 4810, Australia \\ ${ }^{2}$ Department of Soil and Water, EARTH University, Apto. 4442-1000, San José, Costa Rica \\ ${ }^{3}$ Present address: Marine Lab, University of Guam, Mangilao, Guam 96923
}

\begin{abstract}
Direct and lethal natural disturbances to coral reef fish assemblages are rare, as the fishes mobility usually allows for rapid migration away from such events. However, in 1989 and again in 2002, coral spawn 'slicks' off Coral Bay in Western Australia caused many reef organisms to be asphyxiated resulting in catastrophic mortality. A survey in 2002 revealed significant recovery of hard corals within the area disturbed in 1989 (6 to $32 \%$ ), but little recovery of the fish assemblages with their structure being highly skewed towards herbivorous species. The lack of recovery in the fish assemblages was unexpected for 2 reasons: (1) the existence of healthy fish populations in adjacent areas and (2) the well-known positive association between many species of reef fish and their benthic habitat. We identified a combination of minimal recruitment to the disturbed area of the bay and a significantly changed coral community structure to be likely causes of the prolonged recovery process. Although just as lethal to the reef community, the 2002 disturbance was significantly smaller and patchy in its extent. In contrast to the 1989 event, the overall effects of this smaller disturbance were positive with species richness and abundance of fish increasing during the weeks after the event, primarily via migration from nearby areas of reef. Together, these results demonstrate the importance of scale when defining disturbance outcomes on coral reefs and highlight the significant role that 'local' factors can play in mediating outcomes from disturbance. This type of information is especially pertinent to reef managers trying to formulate effective plans for conservation of their local reef systems.
\end{abstract}

KEY WORDS: Community dynamics · Coral spawning $\cdot$ Disturbance $\cdot$ Herbivores $\cdot$ Monitoring Recruitment

Resale or republication not permitted without written consent of the publisher

\section{INTRODUCTION}

The roles of a range of natural disturbances in influencing coral reef community dynamics have been extensively investigated, e.g. storms (Done 1992, Dollar \& Tribble 1993, Cheal et al. 2002, Halford et al. 2004), crown-of-thorns starfish Acanthaster planci infestations (Chesser 1969, Colgan 1987, Hart \& Klumpp 1996, Hart \& Russ 1996, Hart et al. 1996, Lourey et al. 2000) and bleaching (Berkelmans \& Oliver 1999, Aronson et al. 2000, Edwards et al. 2001, Berkelmans et al. 2004, Graham et al. 2006). All of these disturbances affect coral communities directly, but their effects on fish communities are mostly indirect. There have been some direct effects on fish assemblages through intense storms (Lassig 1983, Walsh 1983), cold temperatures (Bohnsack 1983) and phytoplankton blooms (Abram et al. 2003), but they remain, for the most part, a rare occurrence on coral reefs.

A recent study, however, documented the recovery of reef fish assemblages at Mururoa Atoll, French Polynesia, after underground nuclear testing (Planes et al. 2005). While the benthic habitat appeared undisturbed by the detonations, the fish assemblages were severely affected, with multiple instantaneous removal of fish over areas of approximately $12.5 \mathrm{~km}^{2}$ (Planes et al. 2005). The fish community displayed remarkable resilience by recovering to a similar structure within 1 to 
$5 \mathrm{yr}$ of the tests (Planes et al. 2005). A similar outcome of rapid and deterministic recovery by fish assemblages from direct and catastrophic disturbance was also recorded by Syms \& Jones (2000), although at a much smaller scale. After completely removing resident fish assemblages from otherwise undisturbed small patch reefs, they observed recovery of fish assemblages to their pre-removal structure within 3 mo.

Both of these studies concluded that the deterministic nature of the recovery was mediated by the unchanged structure of the resident benthic communities and the 'health' of the greater area surrounding the disturbed zones. However, what happens if the benthic communities are also destroyed? In 1989 severe weather removed up to $95 \%$ of the benthic communities from the northeast flanks of reefs at the southern end of the Great Barrier Reef, yet the benthos recovered to become similar to what existed previously with the fish assemblages then responding similarly (Halford et al. 2004). In contrast Berumen \& Pratchett (2006) found that, although the abundance of corals and butterflyfishes in their study sites on Tiahura Reef, Tahiti, had recovered from numerous disturbances, the species compositions of both the benthic and fish assemblages were very different to what was recorded previously.

A number of studies have identified the underlying rugosity of reef habitat rather than just coral per se as a major structuring force in fish communities (Lewis 1997, Ault \& Johnson 1998, Jones \& Syms 1998, Syms \& Jones 2000). Lewis (1997), for example, found that coral cover had no effect on patch reef-specific patterns of relative abundance in the resident fish communities he was studying and concluded that the underlying heterogeneity of the hard substrata at each patch reef was affecting the composition of the fish communities independently of variations in coral cover. Hence, recovery of a fish community is also likely when coral cover has been significantly reduced but structural complexity remains, such as after a bleaching or crown-of-thorns starfish disturbance, or in this case after coral mortality through anoxia.

In March 1989 an unusual disturbance occurred within a small bay situated on the northwestern coast of Australia (Fig. 1a). Corals within this bay spawned under anomalously benign conditions, effectively restricting the dispersal of the subsequent 'slicks' of coral spawn out of the immediate area (Simpson et al. 1993).
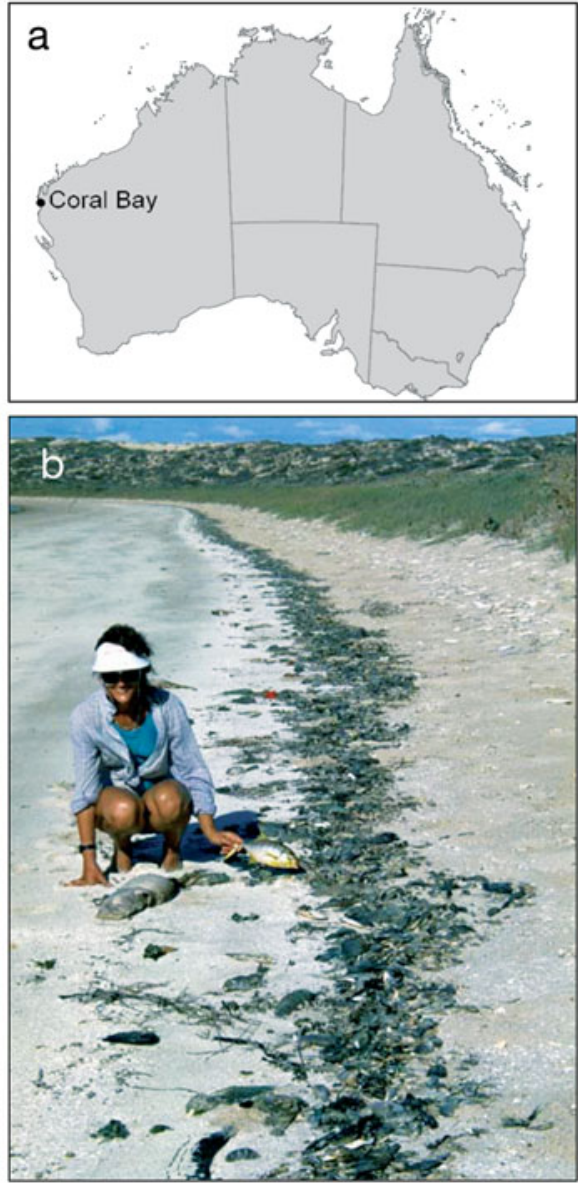
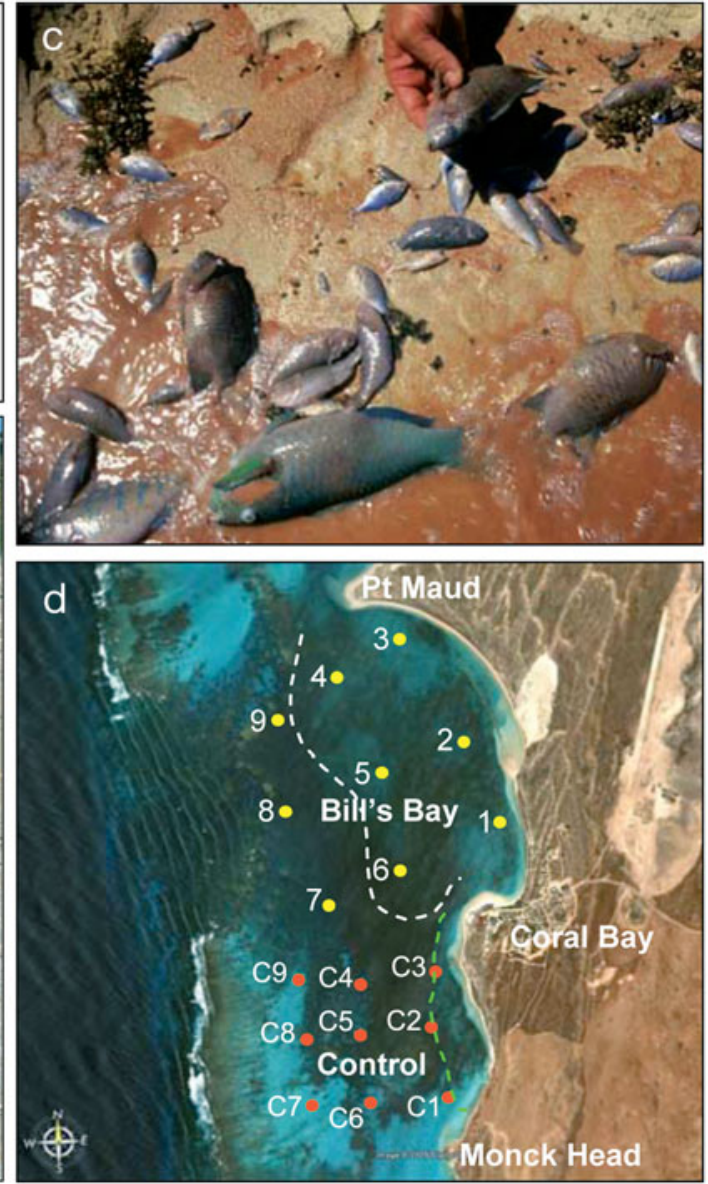

Fig. 1. (a) Location of Coral Bay, Western Australia. (b) Researcher examining the decomposing remains of fish and other organisms from the March 1989 coral spawning event in Bill's Bay. (c) Recently killed parrotfishes and damselfishes from the April 2002 coral spawning event in the inner control bay. The reddish scum is coral spawn; this colour indicates how recent the mortality event was at the time the picture was taken. (d) Position of the survey sites within Bill's Bay and the control bay. The dashed lines indicate the outer extent of mortality caused by the 2 disturbances 
Oxygen levels fell precipitously, resulting in a major proportion of the coral reef community being killed within the inner half of the bay (Simpson et al. 1993). More than 1 million fish representing at least 80 species were washed up on the beach (Fig. 1b) with a similar number of dead fish remaining in the water (Simpson et al. 1993, C. J. Simpson pers. comm.). Hard corals were also devastated with cover decreasing from 42.9 to $9.4 \%$ in the affected area (Simpson et al. 1993). The first post-disturbance survey of fish and coral was completed in 1995 and highlighted the extent of the disturbance and its continued effects 6 yr later (Halford 1997). In April 2002 another similar disturbance event was recorded in an adjacent bay (herein called the control). Although much smaller in spatial extent the immediate effects of this later disturbance were similar (Fig. 1c) with extensive coral and fish mortality within the affected area. This is the first study to report on the effects of simultaneous mortality to corals and fish and, as such, offers insights into fish-habitat relationships from a rarely seen perspective.

We report on the progress of recovery from the 1989 disturbance in Bill's Bay in Western Australia since 1997 and on the short-term effects of the 2002 disturbance in the control bay. Previous work on fish-habitat relationships allows some predictions to be tested regarding the likely outcomes of the recovery process within Bill's Bay. Although extensive mortality occurred in both the fish and benthic communities we predict that with the prevalence of healthy reef communities immediately adjacent to the disturbed areas, and with the skeletons of dead corals remaining largely intact within the very sheltered bay, recovery of the benthic and fish communities is likely. However, given the simultaneous demise of fish and live coral this recovery may be slower than otherwise. Whether the fish assemblages can regain their former structure will depend on the degree to which the benthic communities also recover their pre-disturbance structure. In the absence of any other major disturbances $10 \mathrm{yr}$ is a median time frame noted for recovery from natural disturbances (Connell 1997, Sano 2000, Halford et al. 2004, Downing et al. 2005).

\section{MATERIALS AND METHODS}

Study area. The area where this study was undertaken lies within the Ningaloo Reef Marine Park on the central coast of Western Australia (Fig. 1a). Ningaloo Reef is a contiguous, fringing reef, $\sim 280 \mathrm{~km}$ long, with a shallow lagoon (mean depth at Australia Height Datum, AHD, is $\sim 2 \mathrm{~m}$ ) ranging in width from 0.5 to $6 \mathrm{~km}$ (Simpson et al. 1993). The study area consists of 2 adjacent bays that share a relatively contiguous coral reef community overlooked by the small township of Coral Bay. The northernmost bay, Bill's Bay, is approximately $2.5 \mathrm{~km}$ wide and $5 \mathrm{~km}$ long and is bounded by Point Maud to the north and Coral Bay Township at the southern end (Fig. 1d). This bay was severely affected by entrained coral spawn slicks in March 1989 (Simpson et al. 1993). The second bay to the south is smaller than Bill's Bay at $3 \mathrm{~km}$ wide and $2.5 \mathrm{~km}$ long and is bounded by the Coral Bay Township to the north and Monck Head to the south.

Survey design. A fish and habitat survey of Ningaloo Marine Park, 2 yr before the initial disturbance by coral spawn slicks, indicated that Coral Bay was the most outstanding area within the Ningaloo Marine Park with respect to the cover of its hard coral communities (Ayling \& Ayling 1987). This was still the case at the time of initiating this study and, hence, the reason why the bay directly adjacent to Bill's Bay was chosen as a comparable site for this study. We recognise that this site was not a perfect control as its reef communities had some differences with Bill's Bay, but it nevertheless provided a comparison of temporal change in a section of undisturbed reef with levels of hard coral cover that were not to be found elsewhere at Ningaloo Reef.

The design for this study was outlined in detail in Halford (1997). Briefly, 9 sites were established within Bill's Bay and the adjacent control bay to the south (Fig. 1d) and $3 \times 50 \mathrm{~m}$ transects were located within each site, running parallel to the shore and separated from each other by 30 to $50 \mathrm{~m}$. Benthic cover on each transect was recorded using a video camera following the standard operating procedure of Page et al. (2001) and the footage analysed in the laboratory using the point sampling technique of Carleton \& Done (1995). Abundances of selected fish species were estimated by visual census following the standard operating procedure of Halford \& Thompson (1994). On the first pass of a transect the relatively large and mobile fish species from the families Acanthuridae (surgeonfishes), Chaetodontidae (butterflyfishes), Labridae (wrasses), Lethrinidae (emperors), Lutjanidae (snappers), Serranidae (groupers), Scaridae (parrotfishes), Siganidae (rabbitfishes) and Zanclidae (Moorish idol) were counted along a $5 \mathrm{~m}$ wide corridor. On a return pass along the same transect, the smaller site-attached species from the family Pomacentridae (damselfishes) were counted along a $1 \mathrm{~m}$ corridor.

Our initial survey was carried out in May 1995 and the results compared with those of Simpson et al. (1993) to monitor the rates of recovery in the years since 1989 (Halford 1997). Apart from the dead fish on the beach there was no quantitative data available on the fish assemblages within Bill's Bay prior to 1989; hence, changes in the fish assemblage structure in 
Bill's Bay were assessed relative to the fish assemblages observed in the adjacent control bay. A second survey of the fish and coral assemblages in both bays was completed in May 2002, allowing for a more rigorous assessment of changes in the fish assemblages since 1995. This survey took place only a few weeks after the second smaller disturbance event in the control bay. These results are reported in detail herein. Due to time restraints not all sites surveyed in 1995 could be re-surveyed in 2002. Therefore, effort was concentrated in the inner bay sites where the effects from both disturbances were most pronounced. Hence, in 1995 all 18 sites were surveyed while in 2002 only Sites 1, 2, 3, 4, 6, 7 and 9 were surveyed in each bay.

Data analyses. Spatio-temporal changes in fish at the assemblage level were investigated using hierarchical clustering and non-metric multidimensional scaling (NMDS). Prior to analysis, fish abundance was summed across transects for all Site $\times$ Year combinations and then converted to a common density (no. fish per $150 \mathrm{~m}^{2}$ ). This was necessary because 2 transect widths were used to count fish. Clustering and NMDS ordination was performed on a matrix of Bray-Curtis similarities calculated between all Site $\times$ Year combinations, from a data matrix of $\ln (x+1)$ transformed counts of 44 fish species. This transformation reduces the dominance of the most abundant species, which allows rarer species to have a greater influence in the analysis. Exploratory analysis of the data set using the BVSTEP procedure in PRIMER (Clarke \& Warwick 2005) revealed 8 species were providing the bulk of the structure in the data. These species were subsequently plotted as vectors on the NMDS ordination to indicate their contributions to the overall patterns. Species' scores were calculated as weighted correlations between the original species vectors and the first 2 NMDS ordination axes (see Legendre \& Gallagher 2001, p. 278 for calculation details).

A linear mixed effects (LME) model was used to test for disturbance effects on hard coral cover, fish species richness and abundance between 1995 and 2002. These models offer a useful alternative to standard linear models because the data are permitted to exhibit correlation and non-constant variability. By providing the flexibility to model not only the means of the data, their variances and covariances, unbalanced or missing data, or data collected at different times can also all be accommodated (Lindstrom \& Bates 1990). Only those species with a percentage occurrence of $>10 \%$ across all 96 Site $\times$ Year combinations were considered for the LME analysis with one exception, the damselfish Stegastes lividus, which was included because it was very common at a few sites. To stabilise variances and ensure normality of the residuals all abundances were either square root or natural log trans- formed prior to application of the LME model. Those species for which residuals remained highly nonnormal even after transformation were discarded from any further investigation.

The LME model was fixed with respect to Treatment (the control bay or Bill's Bay), Location (inner, mid or outer part of each bay), and Year (1995 or 2002). Year was not considered a repeat effect due to the 7 yr gap between surveys. Sites and Transects were treated as random effects. Comparisons of estimated means were used to test for significant differences in individual factors and their interactions. Bonferroni corrections were applied to all comparisons to decrease the chances of Type I errors when multiple comparisons are made.

Hard coral cover from the surveys was input to a contouring and surface mapping program (Surfer, Golden Software) to illustrate the spatio-temporal dynamics of coral recovery at Bill's Bay and the control bay. In combination with the Linear Mixed Model analysis this map provides an easily interpretable picture of the changes in hard coral abundance between 1995 and 2002.

\section{RESULTS}

\section{Hard corals}

Immediately prior to the major disturbance in March 1989, hard coral cover averaged $\sim 42 \%$ throughout Bill's Bay (Simpson et al. 1993). As a result of the disturbance coral cover declined to $\sim 5 \%$ within the inner and middle parts of the bay, while the remainder was left undisturbed in the outer part of the bay. Six years later, in 1995, when this study was initiated, hard coral cover at the inner and middle sites within Bill's Bay had shown little recovery, averaging $6.4 \%$ (Halford 1997). However, by 2002 hard coral cover approached pre-1989 levels, having increased 5-fold to $~ 32 \%$ within the affected area of Bill's Bay (Fig. 2a). In the outer part of Bill's Bay coral cover was $\sim 62 \%$, an increase of $20 \%$ compared with pre-impact levels. However, hard coral community structure had not returned to its pre-impact state. Faviids were dominant at many sites where previously Acropora prevailed. Nonetheless, recovery trajectories at most sites indicate that the benthic community is evolving towards its pre-impact condition as Acropora species regain a foothold (van Schoubroeck \& Long 2007). The hard coral community adjacent to Site 1, for example, has recovered its pre-disturbance Acropora-dominated structure (van Schoubroeck \& Long 2007) .

In contrast to the Bill's Bay hard coral community, coral cover averaged $\sim 45 \%$ throughout the control sites in 1995, increasing slightly at the middle and outer sites 
a

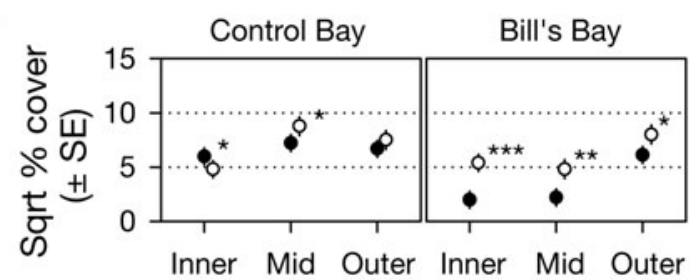

b

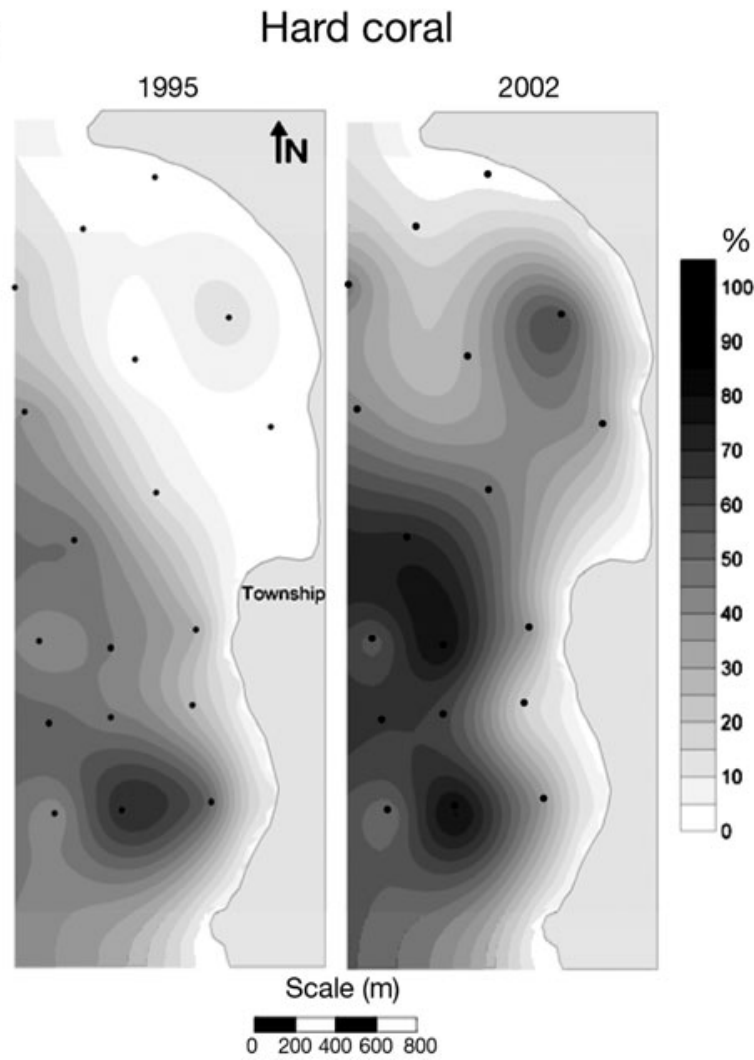

Fig. 2. (a) Hard coral cover by treatment and location, as estimated by the linear mixed effects (LME) model. If transformation was necessary for the LME analysis, then transformed data was plotted. Significant differences between years for any given Treatment $\times$ Location are indicated thus: ${ }^{*} \mathrm{p}<0.05,{ }^{* *} \mathrm{p}<0.001,{ }^{* * *} \mathrm{p}<0.0001 ;$ ○: 1995; O: 2002. (b) Spatial contour plots of hard coral cover within the control bay and Bill's Bay (see Fig. 1d) for 1995 and 2002. The shading scale represents the percentage cover of hard coral. The dots indicate the positions of the survey sites within each bay

by 2002. As a result of the spawning disturbance in April 2002, there was, however, a small decline in hard coral cover at the inner control sites, from 36.8 to $32 \%$, which was marginally insignificant at $\mathrm{p}=0.053$ (Fig. 2a). This decline was most pronounced at the middle inner control site, Site C2 (Fig. 2b). Although coral mortality following the second disturbance in 2002 was as high as $100 \%$ in some areas (e.g. Site C1, Transect 3, Fig. 3) the overall effect was patchy with only 4 of the 9 transects significantly affected (Fig. 3).

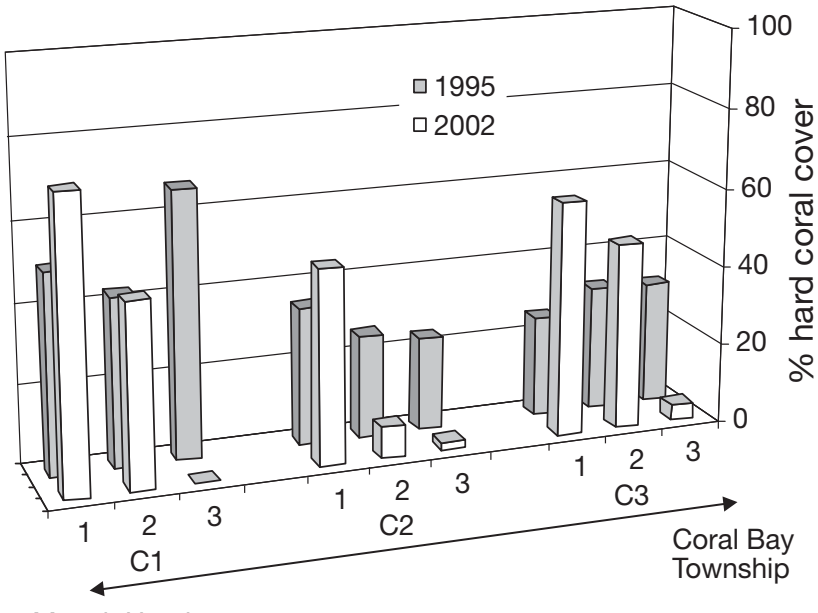

Monck Head

Fig. 3. Change in hard coral cover between 1995 and 2002 on the 9 transects constituting the inner location within the control bay (see 'Materials and methods' for more details). The spatially patchy mortality effects of the 2002 coral spawn disturbance are evident

\section{Fish assemblages}

There was little quantitative information available on the changes in the fish assemblages at Bill's Bay after the disturbance in March 1989. Nevertheless, some conclusions could be drawn from the composition of the dead fish in the water and washed up on the beach (Fig. 1b). The damselfish Pomacentrus coelestis and the parrotfish Scarus schlegeli constituted $\sim 45 \%$ of the >1 million dead fish on the beach (Halford 1997) and were also a significant part of the dead fish assemblage still in the water (C. J. Simpson pers. comm.). This is circumstantial evidence of the relative dominance of these species within the pre-impact fish assemblage residing within the mid and inner parts of Bill's Bay. Additionally, a Ningaloo Reef-wide study of fish abundance conducted 2 yr before the disturbance indicated $S$. schlegeli to be the most abundant scarid throughout Ningaloo Reef (Ayling \& Ayling 1987). In 1995 S. schlegeli was a dominant member of the fish assemblage and remained so in 2002. However, numbers of $P$. coelestis have never recovered, with only a few individuals seen in 1995 and 2002 (Table 1).

The major pattern in the fish assemblages, as identified by clustering and NMDS ordination, was the separation of sites affected by coral spawn from all other sites (Figs. 4 \& 5). Four main groups were identified, separating out from right to left on the first NMDS ordination axis, along a gradient of increasing disturbance intensity. The most 'disturbed' group contained the 3 innermost sites in Bill's Bay, which clustered together across years (Fig. 4) indicating minimal change in the 
Table 1. Relative abundance (\%), by Treatment and Year, for all species within the families Acanthuridae, Chaetodontidae, Scaridae and Pomacentridae

\begin{tabular}{|c|c|c|c|c|}
\hline \multirow{2}{*}{$\begin{array}{l}\text { Family } \\
\text { Species }\end{array}$} & \multicolumn{2}{|c|}{ Control } & \multicolumn{2}{|c|}{ Affected } \\
\hline & 1995 & 2002 & 1995 & 2002 \\
\hline \multicolumn{5}{|l|}{ Acanthuridae } \\
\hline Acanthurus dussumieri & 0.0 & 1.9 & 1.5 & 0.9 \\
\hline A. grammoptilus & 11.1 & 5.0 & 4.6 & 5.4 \\
\hline A. nigrofuscus & 11.1 & 2.5 & 13.8 & 5.9 \\
\hline A. triostegus & 66.7 & 82.5 & 72.3 & 84.2 \\
\hline Ctenochaetus striatus & 0.0 & 3.8 & 3.1 & 0.0 \\
\hline Naso unicornus & 0.0 & 3.1 & 1.5 & 0.5 \\
\hline Zebrasoma scopas & 0.0 & 1.3 & 3.1 & 2.7 \\
\hline Z. veliferum & 11.1 & 0.0 & 0.0 & 0.5 \\
\hline Total (N) & 18 & 160 & 65 & 222 \\
\hline \multicolumn{5}{|l|}{ Chaetodontidae } \\
\hline Chaetodon aureofasciatus & 6.6 & 4.9 & 3.6 & 4.4 \\
\hline C. assarius & 4.9 & 0.8 & 3.6 & 0.0 \\
\hline C. auriga & 9.0 & 14.6 & 2.4 & 9.7 \\
\hline C. citrinellus & 0.0 & 0.8 & 0.0 & 0.0 \\
\hline C. lineolatus & 3.3 & 1.2 & 0.0 & 0.0 \\
\hline C. lunula & 2.5 & 2.4 & 1.2 & 2.7 \\
\hline C. plebius & 59.8 & 49.8 & 70.2 & 65.5 \\
\hline C. speculum & 2.5 & 0.8 & 0.0 & 0.0 \\
\hline C. trifascialis & 10.7 & 23.1 & 2.4 & 0.0 \\
\hline C. trifasciatus & 0.8 & 1.2 & 16.7 & 15.9 \\
\hline C. unimaculatus & 0.0 & 0.0 & 0.0 & 0.9 \\
\hline Chelmon marginalis & 0.0 & 0.4 & 0.0 & 0.9 \\
\hline Total $(\mathbf{N})$ & 122 & 247 & 84 & 113 \\
\hline \multicolumn{5}{|l|}{ Pomacentridae } \\
\hline Cheiloprion labiatus & 0.8 & 0.6 & 0.6 & 0.0 \\
\hline Chromis atripectoralis & 21.9 & 12.7 & 15.9 & 27.7 \\
\hline Dascyllus aruanus & 29.8 & 29.1 & 11.6 & 12.9 \\
\hline D. reticulatus & 0.2 & 0.3 & 0.3 & 0.0 \\
\hline D. trimaculatus & 0.5 & 0.4 & 0.0 & 0.0 \\
\hline Dischistodus spp. & 0.5 & 0.3 & 1.2 & 0.4 \\
\hline Neoglyphidodon melas & 0.9 & 4.5 & 0.0 & 0.6 \\
\hline $\begin{array}{l}\text { Plectroglyphidodon } \\
\text { johnstonianus }\end{array}$ & 0.0 & 0.1 & 0.0 & 0.0 \\
\hline P. lacrymatus & 11.8 & 10.3 & 14.1 & 13.9 \\
\hline Pomacentrus coelestis & 0.8 & 0.1 & 3.4 & 0.3 \\
\hline P. moluccensis & 18.4 & 19.4 & 38.2 & 34.5 \\
\hline P. nagasakiensis & 0.2 & 0.0 & 0.0 & 0.0 \\
\hline P. vaiuli & 3.2 & 1.7 & 0.6 & 0.1 \\
\hline Stegastes lividus & 4.9 & 15.1 & 1.5 & 5.9 \\
\hline S. nigricans & 0.9 & 2.0 & 5.8 & 1.5 \\
\hline S. obreptus & 5.4 & 3.3 & 6.7 & 2.2 \\
\hline Total (N) & 652 & 691 & 327 & 676 \\
\hline \multicolumn{5}{|l|}{ Scaridae } \\
\hline Cetoscarus bicolor & 0.2 & 0.0 & 0.0 & 0.0 \\
\hline Hipposcarus longiceps & 1.5 & 1.3 & 1.1 & 1.5 \\
\hline Scarus chameleon & 1.5 & 0.5 & 1.2 & 0.8 \\
\hline S. frenatus & 1.7 & 1.7 & 0.7 & 0.3 \\
\hline S. ghobban & 9.2 & 4.7 & 4.0 & 2.4 \\
\hline S. microrhinos & 8.6 & 3.6 & 0.6 & 0.9 \\
\hline S. oviceps & 0.0 & 0.4 & 0.0 & 0.0 \\
\hline S. prasiognathus & 1.7 & 3.9 & 0.2 & 1.0 \\
\hline S. psittacus & 0.0 & 0.4 & 0.0 & 0.0 \\
\hline S. rivulatus & 3.9 & 4.4 & 2.8 & 2.3 \\
\hline S. schlegeli & 41.9 & 51.1 & 65.1 & 58.5 \\
\hline S. sordidus & 29.7 & 28.0 & 24.1 & 32.2 \\
\hline Total (N) & 465 & 1116 & 964 & 1301 \\
\hline
\end{tabular}

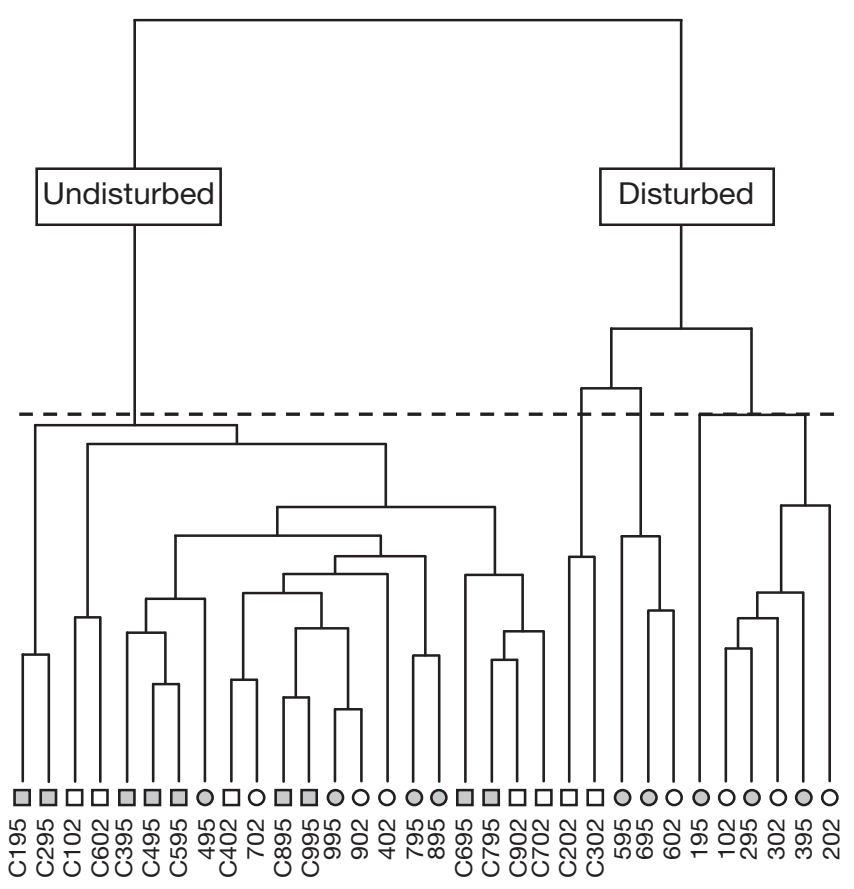

Fig. 4. Dendrogram illustrating the spatio-temporal relationships between the fish assemblages recorded at each site in 1995 and 2002. The abundance data matrix of 44 fish species was $\ln (x+1)$ transformed prior to calculation of Bray-Curtis similarities. Clustering was performed using UPGMA. The horizontal dashed line indicates 4 main groupings at $55 \%$ similarity. The last 2 digits of each sampling location represent the year of sampling. The control sites all start with a C. Symbols are grey: 1995, open: 2002, square: control bay, circle: Bill's Bay

inner Bill's Bay fish assemblages through time relative to the other groupings. Sites 5 and 6 from the middle part of Bill's Bay also clustered together across years. Although Site 4 in Bill's Bay was within the disturbed zone in 1989 it does not have relatively depauperate fish assemblages, grouping as it does with other unaffected sites. In addition to those sites affected by the much larger disturbance in 1989 there was also a clear change in the structure of the fish assemblages associated with the inner control Sites C2 and C3, which are the sites where corals were affected by the 2002 disturbance (Figs. 4 \& 5). The NMDS biplot of the 8 most influential species highlights the fact that affected sites are different because their assemblages are depauperate in most species relative to the other sites. The 2 parrotfishes, Scarus schlegeli and S. sordidus, are the dominant components of the disturbed fish assemblages (Fig. 5, Table 1).

In 2002 the fish assemblages on the inner and mid Bill's Bay sites remained characterised by significantly lower species richness than all other sites in either Bill's Bay or the control bay (Table 2, Fig. 6). When total species richness was partitioned by family it 


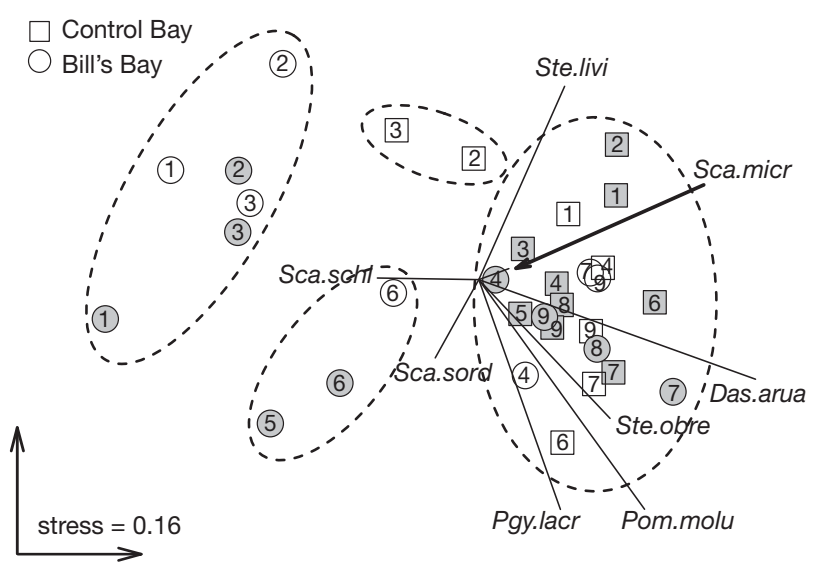

became apparent that the lower species richness was primarily due to the paucity of damselfish species (Table 1, Fig. 6). The only fish species inhabiting this part of the bay in large numbers relative to the other sites were the parrotfishes Scarus schlegeli and S. sor-
Fig. 5. Non-metric multidimensional scaling ordination of all Site $\times$ Year combinations. The similarity matrix underlying the analysis was the same one used for clustering. The 4 main groupings identified from the dendrogram are encircled. Biplots of the 8 fish species most responsible for the observed patterns are superimposed. Species were identified through the SIMPER routine in PRIMER (see 'Materials and methods' for more detail) Das.arua: Dascyllus aruanus; Pgy.lacr: Plectroglyphidodon lacrymatus; Pom.molu: Pomacentrus moluccensis; Sca.micr: Scarus microrhinos; Sca.schl: Scarus schlegeli; Sca.sord: Scarus sordidus; Ste.livi: Stegastes lividu; Ste.obre: Stegastes obreptus. Numbers 1 to 9 represent site locations. Symbols match those in Fig. 4

didus and the surgeonfish Acanthurus triostegus (Table 1, Fig. 7). While coral-associated species were poorly represented within the affected area of Bill's Bay, this was not the case at the undisturbed outer sites where the most common coral-associated pomacentrids, i.e. Chromis atripectoralis, Dascyllus aruanus and Pomacentrus moluccensis, all increased in abundance between 1995 and 2002 (Table 2, Fig. 7).

Table 2. Results of the LME analysis by treatment (T), location (L), year (Y) and their interaction terms for the dependent variables of hard coral, species richness and abundance of the main fish families Acanthuridae (A), Chaetodontidae (C), Labridae (L), Scaridae (S) and Pomacentridae (P), and for abundance of selected species within each family. Significant results are indicated by ${ }^{*} \mathrm{p}<0.05,{ }^{* *} \mathrm{p}<0.001$ and ${ }^{* * *} \mathrm{p}<0.0001$; ns: not significant. Planned comparisons were made between years for each Treatment $\times$ Location combination with significant results annotated to the relevant graphics

\begin{tabular}{|c|c|c|c|c|c|c|c|}
\hline \multirow{2}{*}{ Dependent variables } & \multirow{2}{*}{$\begin{array}{c}\text { Treatment } \\
\mathrm{T}\end{array}$} & \multirow{2}{*}{$\begin{array}{c}\text { Location } \\
\text { L }\end{array}$} & & & - Year - & \multirow[b]{2}{*}{$\mathrm{L} \times \mathrm{Y}$} & \multirow[b]{2}{*}{$\mathrm{T} \times \mathrm{L} \times \mathrm{Y}$} \\
\hline & & & $\mathrm{T} \times \mathrm{L}$ & $\mathrm{Y}$ & $\mathrm{T} \times \mathrm{Y}$ & & \\
\hline Hard coral & $* *$ & $*$ & * & ${ }^{* * *}$ & $* * *$ & ns & * \\
\hline \multicolumn{8}{|l|}{ Species richness } \\
\hline Acanthuridae & * & $\mathrm{ns}$ & $\mathrm{ns}$ & ${ }^{* * *}$ & ns & ns & $\mathrm{ns}$ \\
\hline Chaetodontidae & ${ }^{*}$ & $\mathrm{~ns}$ & ns & ${ }^{* *}$ & ns & ns & $\mathrm{ns}$ \\
\hline Scaridae & ** & $\mathrm{ns}$ & ns & ${ }^{* * *}$ & ns & ns & * \\
\hline Pomacentridae & $* * *$ & $* * *$ & $* *$ & ns & ns & ns & ns \\
\hline \multicolumn{8}{|l|}{ Abundance } \\
\hline Acanthuridae & $\mathrm{ns}$ & $\mathrm{ns}$ & ns & ${ }^{* * *}$ & ns & ns & $\mathrm{ns}$ \\
\hline Chaetodontidae & $\mathrm{ns}$ & $\mathrm{ns}$ & ns & ${ }^{* * *}$ & ns & * & $\mathrm{ns}$ \\
\hline Scaridae & $\mathrm{ns}$ & ns & ns & $* *$ & $* *$ & * & $*$ \\
\hline Pomacentridae & $* *$ & $* * *$ & $* *$ & ${ }^{* *}$ & $* *$ & ns & ns \\
\hline \multicolumn{8}{|l|}{ Species abundance } \\
\hline Acanthurus triostegus (A) & ns & ns & ns & $* * *$ & ns & ns & ns \\
\hline Chaetodon auriga (C) & $\mathrm{ns}$ & $\mathrm{ns}$ & $\mathrm{ns}$ & ${ }^{* * *}$ & $\mathrm{~ns}$ & ns & $\mathrm{ns}$ \\
\hline C. plebius $(\mathrm{C})$ & ns & ns & ns & $*$ & ns & $* *$ & ns \\
\hline C. trifascilais $(\mathrm{C})$ & $*$ & ns & ns & * & $* *$ & ns & ns \\
\hline Epibulus insidiator (L) & ns & $* * *$ & ns & ns & ns & ns & ns \\
\hline Hemigymnus melapterus (L) & * & ns & ns & ns & ns & ns & ns \\
\hline Scarus ghobban (S) & ns & ${ }^{*}$ & ns & ns & ns & ns & ns \\
\hline S. microrhinos (S) & $* *$ & $\mathrm{~ns}$ & ns & ns & $\mathrm{ns}$ & $*$ & $* *$ \\
\hline S. schlegeli (S) & * & $*$ & ns & ns & $* *$ & * & $\mathrm{ns}$ \\
\hline S. sordidius (S) & * & ns & ns & $* * *$ & $\mathrm{~ns}$ & $\mathrm{~ns}$ & $\mathrm{~ns}$ \\
\hline Chromis atripectoralis $(\mathrm{P})$ & ns & ns & ns & ns & $*$ & ns & ns \\
\hline Dascyllus aruanus $(\mathrm{P})$ & $* * *$ & $*$ & $* *$ & ns & $* *$ & $*$ & ns \\
\hline Plectroglyphidodon lacrymatus (P) & ns & $* * *$ & ns & ns & ns & ns & ns \\
\hline Pomacentrus moluccensis $(\mathrm{P})$ & $\mathrm{ns}$ & $* * *$ & $* *$ & ns & $* *$ & $* * *$ & $\mathrm{~ns}$ \\
\hline Stegastes lividus $(\mathrm{P})$ & $* *$ & $*$ & $* * *$ & $* * *$ & ns & $*$ & $* * *$ \\
\hline S. obreptus (P) & ** & $* * *$ & ns & ns & $\mathrm{ns}$ & $\mathrm{ns}$ & $\mathrm{ns}$ \\
\hline
\end{tabular}



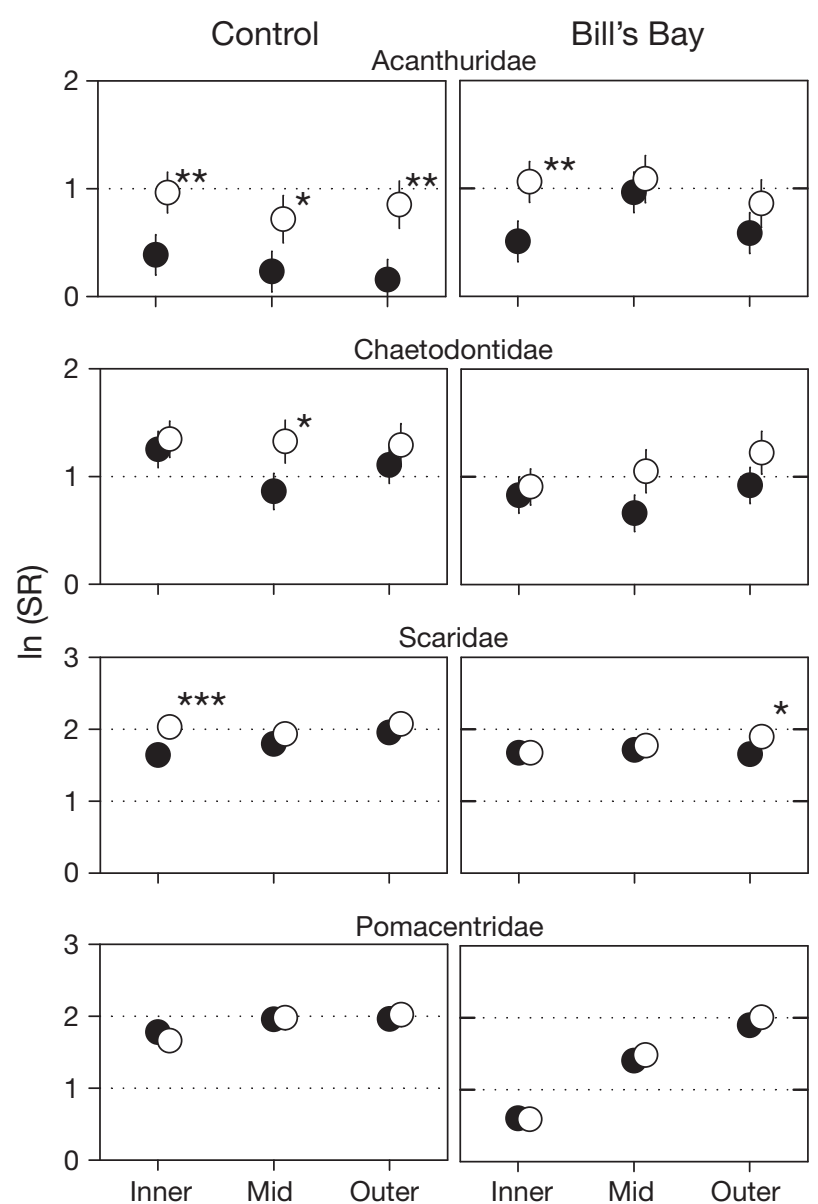

Fig. 6. Species richness (SR) of the families Acanthuridae, Chaetodontidae, Scaridae and Pomacentridae by treatment and location, as estimated by the linear mixed effects model. Symbols as in Fig. 2a

In contrast to the persistent and negative changes on the affected sites in Bill's Bay, species richness actually increased at the more recently affected inner control bay sites (Fig. 6). This was a pattern also manifested at the other undisturbed locations (Fig. 6, Table 1). Nevertheless, there were still significant decreases in the abundance of the coral-associated damselfishes Dascyllus aruanus and Pomacentrus moluccensis within the inner control bay sites (Fig. 7, Table 2). While some of the coral-associated fishes declined at the inner control sites, some species that consume epilithic algae, such as Scarus schlegeli, S. sordidus and Stegastes lividus, all increased in abundance as a result of the disturbance (Fig. 7). For the scarid species, the scale of the increases in abundance at the inner control bay sites was not seen at any of the other sites. There was, however, a large increase in numbers of $S$. lividus at the outer Bill's Bay sites, which was even greater than the increase seen on the disturbed inner control bay sites (Table 1, Fig. 7)
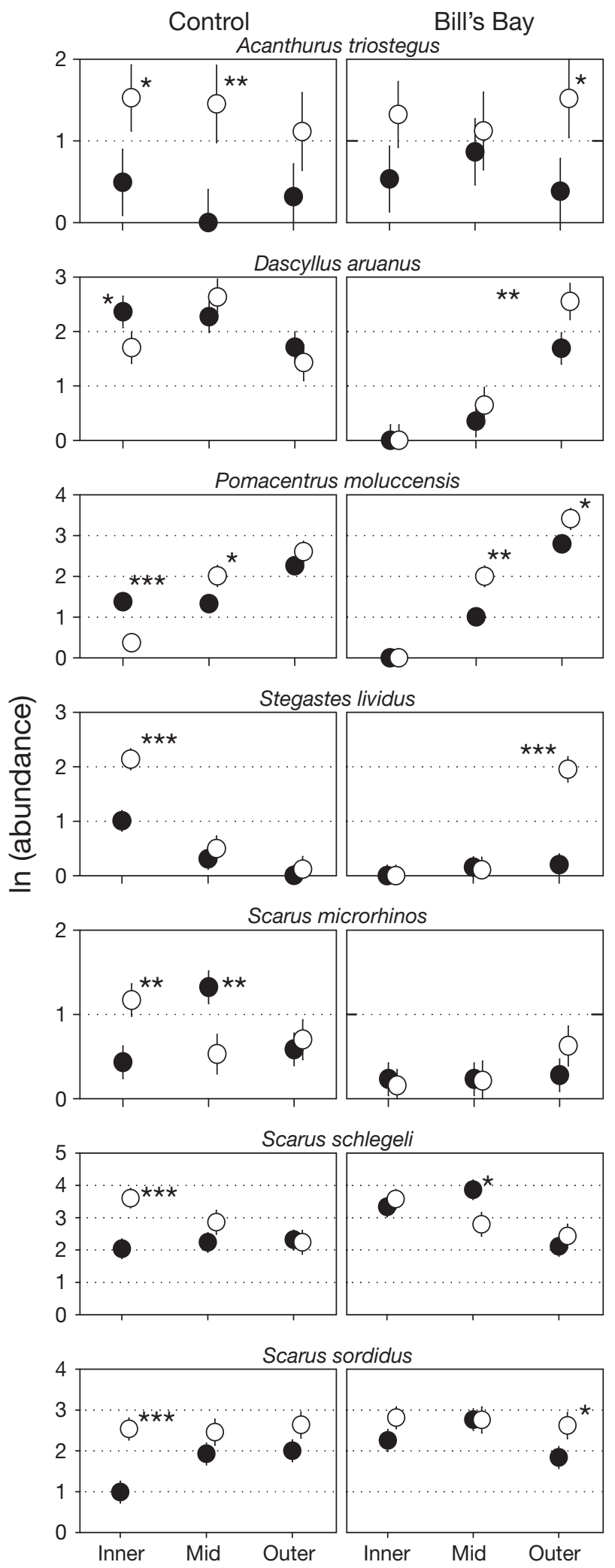

Fig. 7. Abundance of fish species by treatment and location as estimated by the linear mixed effects model. Symbols as in Fig. 2a. Only those species showing significant disturbance effects were plotted 


\section{DISCUSSION}

Although there are ample studies documenting the effects of intense disturbances on coral reef communities (e.g. Chesser 1969, Harmelin-Vivien 1994, Aronson et al. 2000), the nature of the 1989 and 2002 disturbances at Coral Bay nevertheless stand out. The direct removal of significant fish numbers, along with their live coral habitat, was an unusual and destructive event. Mobile organisms, such as fish, usually escape direct disturbance effects either by taking shelter elsewhere, as in the case of storms (e.g. Walsh 1983, Harmelin-Vivien 1994), or because they are not actually targeted such as in cases of bleaching (e.g. Berkelmans \& Oliver 1999) or crown-of-thorns starfish infestation (e.g. Chesser 1969). However, the atypical nature of the disturbance described here provided an opportunity to investigate relationships between fish and their habitat from a perspective not usually possible.

Coral recovery in Bill's Bay was negligible between 1989 and 1995; however, by 2002 percent cover had almost returned to pre-disturbance levels. The time frame of this recovery is consistent with a number of other studies on disturbed coral assemblages (Colgan 1987, Connell 1997, Sano 2000, Halford et al. 2004). Branching and tabulate coral species from the Acroporidae family dominated both Bill's Bay and the control area prior to 1989. Therefore, it was not surprising that this coral family suffered most during the 1989 disturbance, with mortality of $~ 83 \%$ (Simpson et al. 1993). This was also the case during the 2002 disturbance when qualitative assessments of mortality indicated it was almost exclusively branching and tabulate acroporids that were affected (A. R. Halford pers. obs.). While the recovering coral communities were dominated by faviids in 2002, the characteristics of high fecundity, rapid growth and competitive dominance (Stimson 1985, Baird \& Hughes 2000) are enabling acroporid corals to regain their pre-eminence, albeit slowly. A recent report focussing on the recovery of coral communities within Bill's Bay has demonstrated that at least one site within the inner part of Bill's Bay has recovered its pre-impact community structure and that most sites within the affected area are all showing recovery trajectories heading in the same direction, i.e. towards a re-establishment of Acropora dominance (van Schoubroeck \& Long 2007).

While hard coral assemblages were recovering well within the previously affected part of Bill's Bay, this was not the case with the fish assemblages. Species diversity remained low with only a few herbivorous fish species prominent. This was despite ample live coral habitat for locally abundant coral-associated fishes such as Dascyllus aruanus or Pomacentrus moluccensis from the surrounding area to either recruit or migrate to. There are a number of possible reasons for this. Firstly, recovery of absolute abundance without a parallel recovery of pre-impact benthic community structure can result in different fish assemblage associations (e.g. Berumen \& Pratchett 2006) and the coral communities are now faviid rather than Acropora dominated, as was previously the case. Secondly, there is a shallow $(<1 \mathrm{~m})$ raised ridge of live and dead coral that effectively bisects the bay parallel to the shore and encloses the middle and inner parts of the bay. Water temperatures can be up to $4^{\circ} \mathrm{C}$ cooler on the shoreward side of this ridge indicating reduced water flow within the inner bay (Hearn et al. 1986). Reduced water flow has the potential to negatively affect recruitment of both fish and corals to the affected areas. Thirdly, given that the majority of live coral is adjacent to the reef crests where recruits cross over from the plankton to settle on the reef (Doherty \& Mcllwain 1996, McIlwain 2003), this is also the area where most coral-associated fish recruits will settle on the benthos. By the time the inner lagoon area is reached, any given patch of fish has already crossed significant amounts of habitat and, hence, substantial settlement has probably occurred such that very few coral-associated fish remain in the patch (see Lecchini 2005 for a detailed investigation of habitat use strategies by recruiting reef fish).

While the coral-associated fish have not returned to the affected areas in any number, this is not the case for scarid species. Along with Pomacentrus coelestis, scarid species were the most abundant group of dead fish recorded after the 1989 disturbance (Simpson et al. 1993), yet they have been able to recolonise the inner bay area in large numbers. Conditions where a high cover of macroalgae exists within the disturbed area are known to be favourable for these fish species because microalgae are an observed food source for the 2 most abundant scarids, Scarus schlegeli and $S$. sordidius, (A. R. Halford pers. obs.) and provide an optimum habitat for their recruitment (Green 1996). Scarid species are also highly mobile and more likely to move significant distances over the reef in their daily foraging (Chapman \& Kramer 2000).

Of all the fish species affected by the disturbance in 1989, the neon damselfish Pomacentrus coelestis appears to have suffered most. There has been a complete failure of this species to recolonise the inner bay where it was once a dominant species. This is despite the abundance of appropriate habitat suitable for recruiment $-P$. coelestis settlers prefer disturbed habitat with low coral cover (Doherty et al. 1996) and evidence of significant recruitment of this species to other parts of Ningaloo Reef in previous years (McIl- 
wain 2003, Meekan et al. 2003). Significant numbers of $P$. coelestis also exist within the reef passes adjacent to Coral Bay (A. R. Halford pers. obs.). While environmental conditions within the inner bay may retard recruitment, the absolute failure of this species to return to the inner bay is highly correlated with the decimation of the previous adult population and, hence, it is likely that the inner bay population of $P$. coelestis was largely self-seeding. Recovery of this species to the inner bay is uncertain.

Given the time it is taking for the fish assemblages to recover in the inner part of Bill's Bay, this type of disturbance must be relatively infrequent at the scale of the 1989 event, as evidenced by the 12 yr hiatus before the next disturbance of this type occurred, albeit on a much smaller scale. In contrast to Bill's Bay the effects of the 2002 disturbance within the inner part of the control bay appeared to be mostly positive, with species richness and abundance increasing significantly within the disturbed area. The positive nature of the response was probably a reflection of the smaller scale and patchy nature of the coral mortality, which created opportunities without decreasing reef health overall. In addition, the reef surrounding the disturbed area was healthy with relatively high abundance and diversity of fish, some of which may have been attracted to the recently dead corals, which were covered in a dense epilithic turfing algae. This is known to be a preferred food source for some fish species (Wilson et al. 2006).

The increases in species richness and abundance within the inner control area were in fact confined to the families Acanthuridae and Scaridae, both of which contain mostly herbivorous species (Randall et al. 1990). There were no significant family-level changes in either the Chaetodontidae or Pomacentridae, although there were significant changes in some individual species. Given the timing of our survey, within 1 mo of the 2002 disturbance, and the lack of any other obvious disturbance effects, we believe the increase in abundance and diversity of herbivorous fishes within the inner control area must have been due to migration from adjacent areas. This conclusion is supported by a concomitant drop in the abundance of the parrotfishes Scarus schlegeli and S. sordidus from the inner and middle part of Bill's Bay. Scarid species such as these have been found to respond numerically to turfing algae of the type found on newly killed corals (Wilson et al. 2006).

The other dominant species of the post-disturbance fish community in the inner control bay was Stegastes lividus, a territorial herbivorous damselfish (Allen 1991). Because this species defends a territory it is unlikely to migrate as an adult; hence, the increased abundance of this species within the inner control area was most probably due to a successful recruitment event sometime between 1995 and 2002, independent of the disturbance. This species also increased significantly in outer Bill's Bay, where no disturbance has been recorded, reinforcing the likelihood of a recruitment event. Although the staghorn corals which $S$. lividus resides in were dead, their skeletons were still intact and continuing to provide effective shelter for the fish. We expect numbers of $S$. lividus will decline as the dead skeletons erode and eventually collapse.

\section{CONCLUSIONS}

Given the abundance of healthy fish and coral communities surrounding the disturbed area of Bill's Bay we expected recovery of the fish assemblages to be well advanced within 5 to $10 \mathrm{yr}$ of the disturbance, a time frame encapsulating the results of other studies investigating disturbance effects on reef fish (e.g. Sano 2000, Halford et al. 2004, Planes et al. 2005). We also predicted habitat to be a major mediator of fish assemblage structure during the recovery process, irrespective of whether live coral or structure was the primary catalyst. Surprisingly, this has not been the case as the fish assemblages in the inner part of Bill's Bay have remained depauperate of all but a few herbivorous species. While it is difficult to pinpoint what is sustaining the slow recovery of the fish assemblages, it is clear that a considerable time period is required for a coral reef community to recover from a disturbance of such magnitude. Regardless of what factors are influencing the recovery, a significant recruitment event is most probably necessary before the inner bay fish assemblages can regain some semblance of their pre-impact state. However, the lack of recovery by Pomacentrus coelestis indicates such recruitment events are not very common in the inner bay. In contrast to the enduring and negative effects of the 1989 spawning disturbance, the 2002 disturbance provided a positive stimulus, even though the nature of the disturbance was the same. The nature of the smaller disturbance is akin to gaps opening in the canopy of a rainforest and providing an opportunity for other species to exploit (e.g. Connell 1978). The opposing outcomes from the same type of disturbance confirms the multi-scalar nature of coral reef systems (Sale 1998) and highlights the continued need to acknowledge scale when discussing disturbance effects on coral reefs. Moreover, in the continual search for generality in patterns and processes operating on coral reefs our study provides evidence of the influence that 'local' factors can have on outcomes. 
Acknowledgements. Thanks are extended to the staff of the Perth (previously Dampier-based) office of the Australian Institute of Marine Science and the various volunteers who provided assistance in the field. Thank you to Chris Simpson and Jenny Carey for providing data and information (including the photos in Fig. 1b,c) on previous disturbance events at Coral Bay. Comments from Geoff Jones helped improve an earlier draft of the manuscript.

\section{LITERATURE CITED}

Abram NJ, Gagan MK, McCulloch MT, Chappell J, Hantoro WS (2003) Coral reef death during the 1997 Indian Ocean Dipole linked to Indonesian wildfires. Science 301: 952-955

Allen GR (1991) Damselfishes of the world. Mergus Publishers, Melle

Aronson RB, Precht WF, Macintyre IG, Murdoch TJT (2000) Coral bleach-out in Belize. Nature 405:36

> Ault TR, Johnson CR (1998) Spatial variation in fish species richness on coral reefs: habitat fragmentation and stochastic structuring processes. Oikos 82:354-364

Ayling AM, Ayling AL (1987) Ningaloo Marine Park: preliminary fish density assessment and habitat survey, Sea Research, Daintree

Baird AH, Hughes TP (2000) Competitive dominance by tabular corals: an experimental analysis of recruitment and survival of understorey assemblages. J Exp Mar Biol Ecol 251:117-132

Berkelmans R, Oliver JK (1999) Large-scale bleaching of corals on the Great Barrier Reef. Coral Reefs 18:55-60

Berkelmans R, De'Ath G, Kinninmonth S, Skirving WJ (2004) A comparison of the 1998 and 2002 coral bleaching events on the Great Barrier Reef: spatial correlation, patterns, and predictions. Coral Reefs 23:74-83

- Berumen ML, Pratchett MS (2006) Recovery without resilience: persistent disturbance and long-term shifts in the structure of coral and coral communities at Tiahura Reef, Moorea. Coral Reefs 25:647-653

Bohnsack JA (1983) Resiliency of reef fish communities in the Florida Keys following a January 1977 hypothermal fish kill. Environ Biol Fishes 9:41-53

Carleton J, Done TJ (1995) Quantitative video sampling of coral reef benthos: large-scale application. Coral Reefs 14: 35-46

> Chapman MR, Kramer DL (2000) Movements of fishes within and among fringing coral reefs in Barbados. Environ Biol Fishes 57:11?24

Cheal AJ, Coleman G, Miller IR, Delean S, Osborne K, Sweatman H (2002) Responses of coral and fish assemblages to a severe but short-lived tropical cyclone on the Great Barrier Reef, Australia. Coral Reefs 21:131-142

Chesher RH (1969) Destruction of Pacific corals by the sea star Acanthaster planci. Science 165:280-283

Clarke KR, Warwick RM (2005) Change in marine communities: an approach to statistical analysis and interpretation. PRIMER-E, Plymouth Marine Laboratory, Plymouth

Colgan MW (1987) Coral reef recovery on Guam (Micronesia) after catastrophic predation by Acanthaster planci. Ecology 68:1592-1605

- Connell JH (1978) Diversity in tropical rainforests and coral reefs. Science 199:1302-1310

> Connell JH (1997) Disturbance and recovery of coral assemblages. Coral Reefs 16(Suppl):S101-S113

Doherty PJ, McIlwain (1996) Monitoring larval fluxes through the surf zones of Australian coral reefs. Mar Freshw Res
47:383-390

Doherty PJ, Kingsford M, Booth D, Carleton J (1996) Habitat selection before settlement by Pomacentrus coelestis. Mar Freshw Res 47:391-399

Dollar SJ, Tribble GW (1993) Recurrent storm disturbance and recovery: a long-term study of coral communities in Hawaii. Coral Reefs 12:223-233

> Done TJ (1992) Effects of tropical cyclone waves on ecological and geomorphological structures on the Great Barrier Reef. Cont Shelf Res 12:859-872

> Downing N, Buckley R, Stobart B, LeClair L, Teleki K (2005) Reef fish diversity at Aldabra Atoll, Seychelles, during the five years following the 1998 coral bleaching event. Philos Trans R Soc Lond Ser A Math Phys Eng Sci 363:257-261

Edwards AJ, Clark S, Zahir H, Rajasuriya A, Naseer A, Rubens $\mathrm{J}$ (2001) Coral bleaching and mortality on artificial and natural reefs in Maldives in 1998, sea surface temperature anomalies and initial recovery. Mar Pollut Bull 42:7-15

Graham NAJ, Wilson SK, Jennings S, Polunin NVC, Bijoux JP, Robinson J (2006) Dynamic fragility of oceanic coral reef ecosystems. Proc Natl Acad Sci USA 103:8425-8429

Green AL (1996) Spatial, temporal and ontogenetic patterns of habitat use by coral reef fishes (Family: Labridae). Mar Ecol Prog Ser 133:1-11

Halford AR (1997) Recovery of a fish community six years after a catastrophic mortality event. Proc 8th Int Coral Reef Symp, Panama 1:1011-1016

Halford AR, Thompson AA (1994) Visual census surveys of reef fish. Report no. 3. Australian Institute of Marine Science, Townsville

Halford AR, Cheal AJ, Ryan D, Williams DM (2004) Resilience to large-scale disturbance in coral and fish assemblages on the Great Barrier Reef. Ecology 85:1892-1905

Harmelin-Vivien M (1994) The effects of storms and cyclones on coral reefs: a review. J Coastal Res 12:211-231

> Hart AM, Klumpp DW (1996) Response of herbivorous fishes to crown-of-thorns starfish Acanthaster planci outbreaks. I. Substratum analysis and feeding ecology of Acanthurus nigrofuscus and Scarus frenatus. Mar Ecol Prog Ser 132:11-19

> Hart AM, Russ GR (1996) Response of herbivorous fishes to crown-of-thorns starfish Acanthaster planci outbreaks. III. Age, growth, mortality and maturity indices of Acanthurus nigrofuscus. Mar Ecol Prog Ser 136:25-35

> Hart AM, Klumpp DW, Russ GR (1996) Response of herbivorous fishes to crown-of-thorns starfish Acanthaster planci outbreaks. II. Density and biomass of selected species of herbivorous fish and fish-habitat correlations. Mar Ecol Prog Ser 132:21-30

Hearn CJ, Hatcher BG, Masini RJ, Simpson CJ (1986) Oceanographic processes on the Ningaloo coral reef, Western Australia. Dept. Conservation and Land Management, University of Western Australia Environmental Dynamics Report ED-86-171

Jones GP, Syms C (1998) Disturbance, habitat structure and the ecology of fishes on coral reefs. Aust J Ecol 23:287-297

> Lassig BR (1983) The effects of a cyclonic storm on coral reef fish assemblages. Environ Biol Fishes 9:55-63

> Lecchini D (2005) Spatial and behavioural patterns of reef habitat settlement by fish larvae. Mar Ecol Prog Ser 301:247-252

> Legendre P, Gallagher ED (2001) Ecologically meaningful transformations for ordination of species data. Oecologia 129:271-280

> Lewis AR (1997) Effects of experimental coral disturbance on the structure of fish communities on large patch reefs. Mar Ecol Prog Ser 161:37-50 
Lindstrom MJ, Bates DM (1990) Nonlinear mixed effects models for repeated measures data. Biometrics 46:673-687

Lourey MJ, Ryan DAJ, Miller IR (2000) Rates of decline and recovery of coral cover on reefs impacted by, recovering from and unaffected by crown-of-thorns starfish Acanthaster planci: a regional perspective of the Great Barrier Reef. Mar Ecol Prog Ser 196:179-186

McIlwain JL (2003) Fine-scale temporal and spatial patterns of larval supply to a fringing reef in Western Australia. Mar Ecol Prog Ser 252:207-222

Meekan MG, Carleton JH, McKinnon AD, Flynn K, Furnas MJ (2003) What determines the growth of tropical reef fish larvae in the plankton: food or temperature? Mar Ecol Prog Ser 256:193-204

Page C, Coleman G, Ninio R, Osborne K (2001) Surveys of benthic reef communities using underwater video. Report no. 7. Australian Institute of Marine Science, Townsville

Planes S, Galzin R, Bablet JP, Sale PF (2005) Stability of coral reef fish assemblages impacted by nuclear tests. Ecology 86:2578-2585

Randall JE, Allen GR, Steene RC, Steene R (1991) Fishes of the Great Barrier Reef and Coral Sea. Crawford House Press, Bathurst

Editorial responsibility: John Choat,

Townsville, Queensland, Australia
Sale PF (1998) Appropriate scales for studies of reef-fish ecology. Aust J Ecol 23:202-208

Sano M (2000) Stability of reef fish assemblages: responses to coral recovery after catastrophic predation by Acanthaster planci. Mar Ecol Prog Ser 198:121-130

Simpson CJ, Cary JL, Masini RJ (1993) Destruction of corals and other reef animals by coral spawn slicks on Ningaloo Reef, Western Australia. Coral Reefs 12:185-191

Stimson J (1985) The effect of shading by the table coral Acropora hyacinthus on understorey corals. Ecology 66:40-53

Syms C, Jones GP (2000) Disturbance, habitat structure and the dynamics of a coral-reef fish community. Ecology 81:2714-2729

van Schoubroeck P, Long S (2007) Disturbance history of coral reef communities in Bill's Bay, Ningaloo Marine Park, 1989-2007. Marine Science Program, Department of Environment and Conservation, Perth

Walsh WJ (1983) Stability of a coral reef fish community following a catastrophic storm. Coral Reefs 2:49-63

> Wilson SK, Graham NAJ, Pratchett MS, Jones GP, Polunin NVC (2006) Multiple disturbances and the global degradation of coral reefs: Are reef fishes at risk or resilient? Glob Change Biol 12:2220-2234

Submitted: July 25, 2008; Accepted: March 4, 2009 Proofs received from author(s): May 5, 2009 